\title{
Human Security and Sustainable Peace Building in Nigeria: The Niger Delta Perspective
}

\author{
Enu, Donald Bette Ph.D (Corresponding author) \\ Department of Curriculum \& Teaching \\ University of Calabar, Calabar - Nigeria \\ E-mail: bette2004@yahoo.com \\ Ugwu, Ude Ph.D \\ Institute of Public Policy and Administration \\ University of Calabar, Calabar - Nigeria
}

\begin{abstract}
Across the globe, human security and peace building initiative have increasingly assumed prime policy priority necessary for good governance. In Nigeria, this reality has been more pronounced in successive regime failure to face adequately the recurrent Niger Delta challenges for at least the past three decades. This means that peace is neither built on a solid foundation nor has security been achieved. Using the Niger Delta region as a point of focus, the paper examined the interface between human security and peace building and brought to focus the challenges to human security and sustainable peace building in the region. The authors established the fact that human security in the region is predicated upon sustainable peace building and consolidation.
\end{abstract}

Keywords: Human security, Sustainable peace building, Niger Delta, State insecurity

\section{Introduction}

One of the primary roles of the state is to provide peace and security for its citizens both within the nation-state and to ensure their protection against threats from outside (Naidoo, 2000). For every responsible government, human security and peace building concerns should be of utmost priority. Within the framework of global social system, human security has become a contemporary social issue for understanding global dispositions. The supporters of human security and peace building initiative challenge the conventional notion of national security, thus, arguing that the focal point of security should be the individual. They submitted that a people centered security is quintessential for national, regional and global stability. Supporting the above, ElBaradei (2006) expressed the view that humanity quest for peace is not confined to one region as the search for security is still a major concern for people and nations. The current security picture on a global scale is paradoxical as the world has rarely been more peaceful or felt so secure.

Human security is a post cold war concept that involved multidisciplinary understanding. It covers a number of research areas such as development studies, International Relations, Strategic studies and Human Rights. All these are mutually related and overlapping. The turning point for human security began with publication of the 1994 Human Development Report which strongly noted that insuring "Freedom from want" and "Freedom from Fear" for all persons is the best approach to tackle the problem of global security (World summit outcome document, 2005).

A look at the 1994 Human Development Report revealed quite a number of global human security threats with universal applicability. The Niger Delta region of Nigeria is most vulnerable to these threats, ranging from health concerns to infrastructural challenges, bad governance and human rights abuse. The threats also include unemployment, social exclusion to massive poverty. All these put together constitute serious challenges to human security and peace building efforts in the region.

\section{Human Security Dilemma in the Niger Delta}

ElBaradei (2006) made reference to a report on human security to the extent that there seems to be a sharp decline since early 1990s in civil wars and other forms of armed conflict as the number of refugees has also gone down, and human right abuses have decreased. As at that time, the above statistics indicated that the world was becoming more peaceful. Notwithstanding that report, the collective sense of insecurity is now higher than any other time before, because the forces that drive insecurity remain persistent and pervasive. Some of the drivers of insecurity according to the author include: 
Poverty and poverty related insecurities. For those who lack access to reliable food supplies, safe drinking water, adequate health care, and modern energy supplies, all these constitute the most immediate forms of insecurity. The people of the Niger Delta survive on less than one dollar per day. It is quite unfortunate that the region which is seen as the treasure base of the nation has the highest number of the poorest of the poor. Lasting peace can only be achieved when majority of the people are able to break through the shackles of poverty.

- $\quad$ Lack of good governance which is characterized with corruption to severely repressive regimes whose hallmark is human right abuse. This is a typical Nigeria situation. It was worse during the regime of Olusegun Obasenjo, the immediate past president of Nigeria as no difference was made between a military regime and a civilian administration. The then President and Commander-in-Chief of the Armed Forces ordered the army to shoot on sight. This fragrant abuse of fundamental human rights led to the destruction of lives and properties of the entire Odi community in the Niger Delta.

- $\quad$ The high sense of injustice resulting from the imbalance between the 'haves' and 'have nots'.

The social injustice is the crux of the crisis in the Niger Delta as the region is contributing so much to the economic development of Nigeria but getting very little. Unless social justice is sustained, peace and security will continue to be elusive in the Niger Delta.

The above drives of insecurely are succinctly summarized by Kalu (2008) as having constituted serious security issue in the Niger Delta: protracted poor governance, social injustice, poor development, environmental degradation, social and family dislocation as well as bad and corrupt leadership.

The Niger Delta region of Nigeria is richly endowed with huge quantity of petroleum resources. The region has also suffered prolonged neglect and official marginalization right from when petroleum was discovered. The major problem is the disconnection between promises made by successive government right from independence and the reality of post independence to the people of the region. The government is unable to address the deliberate marginalization of the people who are the custodian of the wealth of the nation. Due to low political will on the part of past governments, the people of the region resorted to self help methods to draw government attention towards addressing the problems of the region.

The above background became one identifiable cause of incessant unrest thereby making the region highly volatile. This formed concrete grievances among an identified sub-group highly discriminated against by the majority. According to Ibegbu (2007), it was the actions of Nigerian leaders dominated by the majority Northern Leadership such that it neglected the needs and aspirations of the Niger Delta area. In addition to the above, hostility in the area is traceable to lack of opportunity for political participation which in the words of Ibegbu (2007), regimes that deny access to power and persecute dissenters create dissatisfaction among the people. Given this condition, grievances become primarily political; without social or economic overtures.

Watchers of events in Nigeria will agree that there was an existence of a lack of opportunity for political participation of the people of the Niger Delta even after serious agitations until recently when current regimes adopted certain changes. Even with these, the region is the least developed in the country in terms of basic amenities in comparative terms with other parts of Nigeria. The absence of basic infrastructure justified the involvement of the people of the area in all manner of inhuman operations to draw government attention led by Movement for the Emancipation of the Niger Delta (MEND), the umbrella militant group.

MEND adopted a wide variety of satanic operational methods and criminal activities to sustain its source of financing and unleash terror in the region. Methods such as high profile kidnapping of expatriates, illegal oil bunkering, smuggling, counterfeiting, drug trafficking, arms sale etc to advance its course in addition to political donations by political office holders who believed in the use of violence to attain political power (Ibegbu, 2007).

The inability of the state to address the problem of marginalization of the region led to a sustained agitation. The more the region realized that the failure to meet these demands is deliberate and unjust the more violent the agitation was expressed (Ndoma-Egba, 2000). Questions to ask are: what are the prospects for effective peace building in the Niger Delta region characterized by insecurity? What positive paradigm shifts, in theory and practice is government's effort towards building peace in the region? And in what ways do these positive paradigm shifts shape the conduct of peace building and enhances positive attitude towards human security concerns?

It is only the government that makes fair bargains with her citizens and takes into proper consideration the exigency to provide electricity supply, water supply, communication networks, equity in revenue allocation and provide employment opportunities that will win the trust of her citizens. The possibility of curbing corruption and influencing the citizens to be law abiding will also be achievable. In this way, ushering in a needful sense of security to nullify the rate of crimes committed and the restoration of peace will be less turbulent to administer. 


\section{Interfacing Human Security and Peace Building}

Human security according to Sato (2004) is a concept that bonds peace and development. It is all about liberating humans from physical and artificial hindrances such as war, poverty or political oppression, which prevent people from choosing freely and acting freely on what they have chosen. In a policy speech by Keizo Obuchi, a past Prime Minister of Canada, he explained human security as a concept encompassing all kinds of threats to human survival, human life and human dignity, and requiring strengthened measures to tackle such threats.

According to Conteh-Morgan (2005), an analysis of the relationship between human security and peace building has to begin with a broad conceptualization of human security that takes into consideration the individual situated in a broader social structure. Such a conceptualization should include institutional sources of human security harmful actions and neglect of institutions that undermine human rights and human security. These include among others the collapse of the welfare system, the politicization and the neglect of the military, the unprofessionalism of the paramilitary and the police forces that were once an integral part of the neo-patrimonial system.

Checkel(1997) and Conteh-Morgan(2005) jointly advanced that sustained peace building occurs when one understands the true nature of things in the society - class, gender, ethnic equality etc. We also have individual sources of human insecurity- harmful actions directed against people or properly with visible and immediate consequences. There are banditry, lootings, and intense communal strife among others with women and children being the worst affected. Human security is an important precondition for sustained peace building at any point in time which in turn provides the foundation for regional and global peace and stability. Human security needs national security because the former can only be promoted and sustained in an atmosphere of inter-geopolitical/ zonal peace and stability. Again, national peace can only be promoted and guaranteed if the constituent states experience domestic peace built on secured communities.

The most intriguing aspect of the interface between human security and peace building according to SatÓ (2004) is that human security theory offers theoretical support for peace-building. Peace building means building a society in which positive peace is secured; peace without structural violence such as poverty and discrimination or a society which guarantees human security. It is a society in which individual human rights and social justice are respected. That is to say, it is all about how to transform a conflicting society characterized with conflict, terrorism, violence, civil strife into a peaceful society in which human beings can live freely.

However, when the seven dimensions of human security as contained in the 1994 UNDP human development report which are:
- $\quad$ Economic security,
- $\quad$ Food security,
- Health security,
- $\quad$ Environmental security,
- $\quad$ Personal security,
- $\quad$ Community security and,
- $\quad$ Political security, when there are grossly undermined, then sustainable peace cannot be established.

The above have been identified as typical problem areas which threaten human security. It is however recognized that human insecurity should not be limited to these seven. That is to say that the problem of employment, income food and others are not only problems of development, but problems of human security: thus security and development are two sides of the same coin. It is further recognized that development is related to conflict prevention. For when there is an atmosphere of peace, development is guaranteed .Nevertheless, the UNDP proposal of 1995 during the Copenhagen Declaration on Social Development, confirmed that social development, social justice, and peace as well as security are inseparable. This underscores the UNDP theory of human security which regards social injustice as a structural problem threatening peace and development- a problem which must be tackled.

The expectation is that in the pursuit of human security and peace building, the national institutions must be change agents. These institutions must possess the political will to challenge the status quo. The institutions must be sufficiently empowered and given the mandate to alter and direct the affairs of things for positive change to occur. To pursue human security is to enhance the national capability to advance universal values among the citizens and enthrone development for the good of all. 
Human security is a situation/condition free of injury/threats to individuals, groups, or community well being. These include freedom from threat and direct attacks on physical and psychological integrity. What therefore motivates the dissatisfied to agitate and their beliefs as marginalized individuals should be seriously taken into consideration instead of merely imposing on them the concept of the government of the day.

Peace building with a view to alleviating insecurity involves transforming the social and political environment that fosters intolerable inequality, endangers historical grievances and nurtures adversarial interactions. This may mean the development of social, political, and economic infrastructure that produce tolerable inequality and prevent future violence. When the above are addressed realistically taking into consideration the political, socioeconomic, cultural and other environmental conditions, the quest for true peace building will be achieved.

\section{Challenges to Human Security and Peace Building}

In his reaction to the challenges of sustainable peace in the Niger Delta, Onduke(2003) established that the basis of conflict is the clash of interests, values and goal, as conflict can only be resolved when these are changed. He further indicated that preventing and mitigating the impact of internal violent conflict are not sufficient to achieve peace and stability in today's world. What he suggested was the upholding of human rights, pursuing inclusive and equitable development and respecting human dignity and diversity are very important in the promotion of peace. All these can guarantee human security.

However, it was the United Nation's Human Development Report of 1994 that sharpened the debate on what should be the focus of regional and national effort towards promoting security: should it be the state or the people? Is the pursuit of national security and human security compatible? Which of this should take precedent? Considering that the objective of human security is to safeguard the vital core of all human lives from critical pervasive threats, in a way that is consistent with long term human fulfillment. Human security means protecting fundamental freedoms- freedoms from doubt and freedom that ensures a degree of confidence and assurance amongst members of the state. More challenging is the fact that the preservation of human dignity is the core of human security, human rights and human development. It means using processes that build on people's strengths and aspirations. It implies creating political, social, environmental, military and cultural systems that gives the people the building blocks of survival, livelihood and dignity (Onduke(2003).

In balancing the pursuit of state and human security viz-a-viz peace building, the United State Commission on Global Governance in one of its report indicated that security of people must be regarded as a goal as important as the security of the state. This is considered to be the most pressing security challenge of the $21^{\text {st }}$ century. It is based on this that Abad (2000) observed that human security will always be threatened if there is no inter-state, inter-regional and interethnic peace and stability as the promotion of regional security must remain a legitimate preoccupation of nation-states. As a function of security dilemma, national security, equilibrium and harmony do not just evolve by chance, they have to be conscientiously promoted and managed by credible and responsible leadership. The absence of this quality leadership in Nigeria is responsible for the sustained crisis in the Niger Delta. This was the view of Onduke(2003) declared that "we have had in Nigeria governance with no government, and we have had leadership with no genuine followership. We have long lost the 'One Nigeria' Patriotic zeal. Our leaders have lost the culture of service and imbibed instead a culture of lordship. It is time we make them realize that leadership is call to service. We need their unbiased commitment to the development of all fabrics of the society (Onduke,2003:1). Deliberate and sustained efforts through confidence building and cooperation are essential in promoting peace and stability.

In his address on the Challenges of peace building: reconstructing shattered societies to an audience of 600 in Canada, Michael Ignatieff as reported by Raymer (2006) said peace building must emphatically be comprehensive with four major components. These components may have universal applicability.

They include:

- $\quad$ Consolidation of constitutional democracy
- $\quad$ The development of capacity to collect revenues
-

However, in the case of Nigeria Niger Delta being the focus of this paper, in addition to the requirements above, other challenges to human security and peace building in the region are:

- Suppression of human rights

- Inability to secure oil installations 
-

$\bullet$

$\bullet$

Unequal distribution of oil revenue

Failure to recompense for environmental degradation

Ineffective government agencies

Marginalization of the minority by the majority ethnic groups.

\section{Paradigm for Effective Human Security and Peace Building in the Niger Delta Region}

A search for an effective paradigm for human security and peace-building in the Niger Delta necessarily call for an overhaul of whatever approaches have been utilized which are regarded as mere palliative measures if sustained peace must be guaranteed in that region. Peace building and reconstruction efforts are activities now closely linked with the liberal state building, and in this context human security has become a validation concept of the overall project goal of modern Nation- States. This paper therefore believes that

1) for Nigeria to address the issue of human security and peace building in the Niger Delta, this should be integrated as part of their conflict management governance agenda. It therefore suggests a new paradigm for effective human security and peace building to include:

2) Re-examination of the structural factors driving the crisis(political, economic and socio-cultural),

3) Showing a political will in the establishment of necessary institutions to redistribute the dividends of democracy

4) Re-analysis of the economic, social, historical, cultural, religious and psychological aspects of the people, groups of the society which constitute the Niger Delta.

5) Appreciate the fact that poverty, social injustice, historical hatreds and cultural dislikes are the structural factors of violence at any given time in human history.

Taking a look at the Niger Delta region, given the fact that government hurriedly granted the militants amnesty through intensive cash lobbying and settlement of those who made things happen without corresponding measures to address the root causes of the violence in the area, is just an ad-hoc and time buying tactics of addressing the issue of human security and peace building in the region. The hydra headed problem in the region will certainly rear its head again if there is no sustained paradigm shift in the direction of the above suggestions.

Sató (2004) noted that if a conflict ends through a vote or court case, and if the structure of the conflict remains, the discontent simmers. The conflict is then resolved only through a process which the parties overcome their point of dispute, come to a settlement, and achieve reconciliation. Fundamental cause of human insecurity in the Niger Delta is poverty occasioned by deliberate official neglect of that region. Poverty cannot be solved by mere welfare because it is mostly a result of discrimination and alienation, political power in-balance or lack of access to justice. To address it requires an official affirmative action which guarantees political stability.

Finally, factors such as cultural, historical and religious confrontation have deep roots because they are issues linked with human identity. Therefore, the resolution of factors of conflict must take a long term, generational approach. Such expected measure include expanding opportunities for mutual understanding by appreciating each party condition and then providing an opportunity for them to meet and work as a unified group (Commission on Human Security, 2003).

\section{Conclusion}

Human security and peace building must always remain top priorities of every responsible government and should remain part of management governance agenda. The two initiatives must constitute the foundation of every nation development priority. This is so because development and security are two sides of the same coin. Therefore development challenges must necessarily demand an atmosphere of peace and tranquility. The Niger Delta religion of Nigeria is a very volatile region as it remains a hotspot for all manner of violence. What is sure is that the region, being the treasure base of the nation has suffered all forms of neglect by the government. In an attempt to seek for recognition by the government of the day, the people have to adopt various forms of criminality to advance their course hence, making the region grossly insecure in all ramifications. This forms the basis for the search for human security and peace building in the region. If one adopts a constructionist orientation to human security and peace building, it demands that for peace building to stimulate human security, it must be established on the foundation of secured equal socio-economic and political opportunities of all the people. This implies that all the security threats as contained in the 1994 UNDP report must be taken care of without compromise by the various institutions of governance. This becomes a sure way of attaining human security and sustained peace building in the Nigeria Niger Delta. 


\section{References}

Abad, M. C. (2000). The challenges of balancing state security with human security. A paper presented at the $9^{\text {th }}$ Harvard Project for Asia \& Int'l affairs conference, Beijing, 27-30 August 2000.

Checkel, J. T. (1997). International Norms and Domestic Politics. Bridging the Nationalist Constructivist Divide. European Journal of International Relations. 3, 473 - 495.

The commission on human security (2003). Human Security Now. Oxford University Press: Oxford.

Conteh-Morgan, E. (2005). Peace Building and Human Security: A Constructivist Perspective. International Journal of Peace Study, 10, 1.

ElBaradei, M. (2006). Human Security and the Quest for Peace in the Middle East. A Statement of the Director-General delivered on the $24^{\text {th }}$ October, 2006 at the International Atomic Energy Agency held at Vienna, Austria.

Ibegbu, C. (2007) Niger Delta Terrorism and Militant Group Financing. File:llIC/ Niger Delta military. html 20/11/2009.

Kalu, I.K. (2008). How to fix the Niger Delta Problem. Newswatch Magazine, October 20, 2008.

Naidoo, S. (2001) A Theoretical Conceptualization of Human Security and Conflict Prevention in Africa. Proceedings of the UNESCO-ISS Expert meeting held in Pretoria, South Africa from 23-24 July 2001.

Ndoma-Egba, V. (2004). Forced unity: The Nationality Question. In O. E. Uya (ed) Civil Society and the Consolidation of Democracy in Nigeria. Being proceedings of IPPA seed internationals Seminar held at Chinua Achebe New Arts Theatre, University of Calabar from 25th - 26th May 2000.

Onduke, A. (2003). Confronting the Human Security Dilemma: towards building sustainable peace in Niger Delta. A paper presented at the award ceremony in honour of Ms Ibiba Don Pedro, Winner of the 2003 CNN African Journalist of the year held at the Lambeth Town Council Building London, Saturday $18^{\text {th }}$ October 2003.

Raymer, E. (2006). The Challenges of Peace Building: Reconstructing shattered societies. Peace Magazine, April - June, 15.

SatÓ, Yasunobu. (2004). Human security and peace building: practical research through NGOs. Discussion paper for peace building studies, No. 01 (summer 2004).

UNDP (1994). Human Development Report. Oxford University Press: Oxford.

World Submit Outcome Document. (2005). Culture of peace and initiatives on dialogue among cultures, civilizations and religion. United Nations General Assembly held on $15^{\text {th }}$ September, 2005 at Geneva. 